\title{
Cancer incidence and mortality in rural workers in the Brazilian Western Amazon
}

\author{
Incidência e mortalidade por câncer em trabalhadores \\ rurais na Amazônia Ocidental Brasileira
}

\author{
Emanuela de Souza Gomes dos Santos ${ }^{1 *}$, Creso Machado Lopes², \\ Sergio Koifman ${ }^{3 \dagger}$
}

\begin{abstract}
Aim: To conduct an exploratory study about cancer incidence and mortality in rural workers in the state of Acre, Brazil. Methods: The Proportional Cancer Incidence Ratio (PCIR) was calculated for rural male workers who live in Rio Branco, Acre, with histological diagnosis of cancer, and the Cancer Mortality Odds Ratio (CMOR) comparing cancer deaths occurred in rural workers in the state of Acre with those occurred in people with other occupations in the period from 2007 to 2012. Results: High and statistically significant PCIR were observed for tumors of larynx, PCIR = 7.55 (95\% Cl 4.23-12.46); melanoma, PCIR = 11.44 (95\% Cl 6.5518.54); and non - Hodgkin lymphoma, PCIR $=10.00$ (95\% Cl 5.17-17.50) compared to the population of Rio Branco. Regarding the mortality compared analysis, we can observe CMOR $=6.94(95 \% \mathrm{Cl} 1.73-27.89)$ for pancreatic cancer and CMOR $=13.89$ $(95 \% \mathrm{Cl} 1.25-153.60)$ for cancer of the urinary tract. Conclusion: The results suggest an increase in the incidence estimates of mortality for selected tumor sites among rural workers that are consistent with the literature.
\end{abstract}

Keywords: cancer; occupational activity; rural workers.

Resumo

Objetivo: Realizar um estudo exploratório sobre a incidência e mortalidade por câncer em trabalhadores rurais do estado do Acre, Brasil. Metodologia: Foram calculadas a Razão Proporcional de Incidência de Câncer (PCIR) para os trabalhadores rurais residentes em Rio Branco, Acre, com diagnóstico de neoplasia e a Razão de Chances de Mortalidade por Câncer (CMOR), comparando-se os óbitos por câncer de trabalhadores rurais no estado do Acre com aqueles ocorridos com indivíduos de outras ocupações no período de 2007 a 2012. Resultados: PCIR elevadas e estatisticamente significativas foram observadas para os tumores de laringe, PCIR = 7,55 (95\% IC - 4,23-12,46), melanoma, PCIR = 11,44 (95\% IC - 6,55-18,54) e linfoma não Hodgkin, $\mathrm{PCIR}=10(95 \%$ IC - 5,17-17,50) em relação à população de Rio Branco. Quanto à análise comparada da mortalidade, foram encontradas CMOR = 6,94 (95\% IC - 1,73-27,89) para câncer de pâncreas e CMOR = 13,89 (95\% IC - 1,25-153,60) para neoplasias do trato urinário. Conclusão: Os resultados observados sugerem uma elevação nas estimativas de incidência e mortalidade de localizações tumorais selecionadas entre os trabalhadores rurais, consistentes com a literatura.

Palavras-chave: câncer; atividade ocupacional; trabalhadores rurais.

1'nstituto Federal de Educação, Ciência e Tecnologia do Acre (IFAC) - Rio Branco (AC), Brasil.

${ }^{2}$ Programa de Pós-graduação em Saúde Coletiva, Universidade Federal do Acre (UFAC) - Rio Branco (AC), Brasil.

${ }^{3}$ Escola Nacional de Saúde Pública, Fundação Oswaldo Cruz - Rio de Janeiro (RJ), Brasil.

Study carried out at Universidade Federal do Acre (UFAC) - Rio Branco (AC), Brasil.

Correspondence: Emanuela de Souza Gomes dos Santos - Instituto Federal de Educação, Ciência e Tecnologia do Acre (IFAC), Avenida Brasil, 920 - Xavier Maia - CEP: 69903-068 - Rio Branco (AC), Brasil - Email: emanuela.santos@ifac.edu.br

† In memoriam

Financial support: This investigation was partially funded by the CAPES through the cooperation established between the Federal University of Acre (Masters in Public Health) and the Sergio Arouca National School of Public Health, Oswaldo Cruz Foundation (Public Health and Environment Postgraduate Program) and use of own resources.

Conflict of interests: nothing to declare. 


\section{INTRODUCTION}

Cancer is currently the second leading cause of death worldwide becoming a clear public health problem, both in developed and developing countries. Approximately $30 \%$ of world occurrence of cancer could be avoided, such as occupational related cancers ${ }^{1}$.

The productive activities historically predominant in Acre were rubber extraction, extensive livestock cutting and illegal logging. This occupational process occurred throughout the nineteenth century with the migration of Northeastern workers to Acre which was strongly influenced by the great drought in 1877. Migrants were deluded with easy wealth from the extraction of rubber, which was the product of international interest at that time. This period was known as the First Rubber Boom².

With the decline process of the extractive economy and the consequent rubber plantation bankruptcy during the rubber crisis in 1913, the agriculture was intensified and diversified; it is until now one of the most important economic activities of the region and traditionally performed by male workers ${ }^{2,3}$.

There are several gaps in knowledge concerning cancer due to occupational exposure and many questions need to be answered, especially regarding the exposure of agricultural community to carcinogenic substances. Thus, it is necessary to know more about the incidence characteristics and the mortality caused by these tumors in Brazil, taking into account any regional characteristics.

In this context, to add possible evidence of occupational exposure in the development of carcinogenesis, we analyzed the contribution of the rural workers activities as a risk factor for the incidence and mortality of cancer in Acre in the period of 2007 to 2012.

\section{MATERIAL AND METHODS}

We conducted a descriptive exploratory study on the occurrence of cancer in farmer workers of Acre State - Brazil (Figure 1).

In the first part of this work, the Proportional Cancer Incidence Ratio (PCIR) was determined for a sample of rural workers living in the capital of Acre, Rio Branco. Patients were treated from July/2007 to June/2012 at UNACON, a Unit of Oncology Service in Acre.

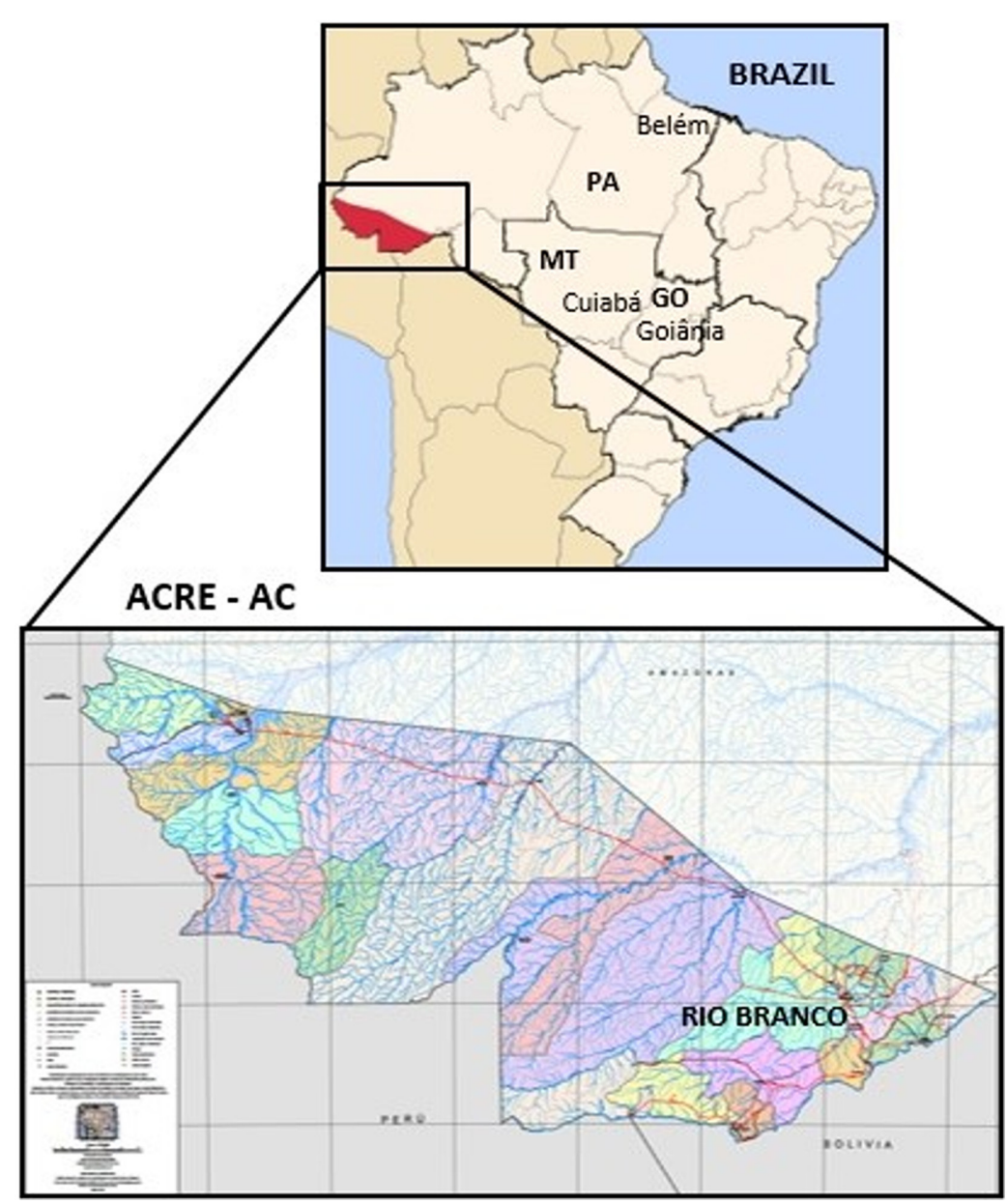

Figure 1. Map of Brazil, including the areas under study - adapted. (Source: IBGE ${ }^{4}$ ) 
In order to have access to the cases of cancer in rural workers, we analyzed the universe of cancer cases recorded at the hospital database during the mentioned period; all cases occurred in male patients at the age of 20 years or older, living in Rio Branco. After checking the selected records, these patients were characterized according to their occupations at the time of admission.

Epidemiological studies of occupational nature seek to understand the exposure process at work. According to experts, the exposure information can be obtained by different methods, including retrieving stored records, as type of work, for example ${ }^{5}$.

Brazil uses the Brazilian Classification of Occupation (CBO) to identify the professions ${ }^{6}$. The $\mathrm{CBO}$ is based on the International Standard Classification of Occupations (ISCO), adopted for the description of occupational activities of this study, enabling the comparison with international studies ${ }^{7}$.

The initial sample was obtained in an electronic record at UNACON and consisted of 958 cancer cases in males in Rio Branco. Afterwards, we searched and reviewed these records in order to confirm the identification data, histopathological examinations and collect the variable occupation. In this research, only 689 medical records were encountered enabling the identification of 184 cases of cancer with histopathological confirmation in males, aged from 20 or older, whose occupation was related to rural labor; these data were used to calculate the PCIR. The other cases had a different occupations, had been retired or their occupational activity could not be identified.

This study assessed rural occupational activities as farmers, rubber tappers or others activities related to rural activities as fishermen, tractor drivers and rural workers, according to the ISCO classification, with 6111- 63406 occupancy codes.

The Proportional Cancer Incidence Ratio (PCIR) was adjusted for age and calculated for each of the anatomical sites of cancer observed among rural workers, according to the methodology described by Hennekens and Buring 8 . For each result, the confidence interval of $95 \%$ was established according to the Poisson distribution?

The PCIR was obtained by calculating the ratio of the number of cases observed in each age group in the set of male patients hospitalized, whose occupation was related to the rural works during the period from 2007 to 2012, and the total number of cases expected in males in each age group according to a specific location. Cases were determined according to Rio Branco Population Based Cancer Estimates Data in 2007-2012 ${ }^{10}$, and according to the data of Population Based Cancer Registries (PBCR) in the cities of Cuiabá, MT, Brazil from 2001 to 2005, Goiânia, GO, Brazil from 2001 to 2005 and Belém, PA, Brazil from 2000 to $2001^{11}$, at the same sex and age (Figure 1). These capitals were chosen because Rio Branco is the city where the study was conducted; Belém is a city in the Amazon region with a significant population based cancer registration. The others - Cuiabá and Goiânia - were chosen because they allow a comparison of the proportional distribution of cancer in rural workers in Acre with that observed in Brazilian cities with a high incidence of cancer in all cancer areas, as well as some specific sites ${ }^{11}$; in addition to having quality records recognized by the IARC (cancer incidence data included in their current international publications, Cancer in Five Continents) ${ }^{12}$.

To determine the expected cases, the cases proportions were calculated in each area of cancer that occurred in males aged from 20 years old or older, according to ages groups from 10 to 10 years, and until 70 years or more, according to form presentation of Rio Branco Population Based Cancer Estimated Data (2007 - 2012) published by Nakashima et al. ${ }^{10}$.

Thus, it was possible to estimate the expected number of cancer cases in a determined anatomic location among rural workers, based on the distribution of cancer cases in the general population used as standard in different cities, according to the methodology of Hennekens and Buring ${ }^{8}$.

The proportions were calculated from the ratio between the number of cases in each anatomical site of cancer of each age group and the total number of cases in all anatomical sites of cancer in their age group. Later, the number of expected cases was determined by the product of the proportions found in each site of cancer according to the age group and the total number of cases of all anatomical sites of cancer in their age group.

The second part of this study was based in calculating the Cancer Mortality Odds Ratio (CMOR) throughout the State of Acre.

This analysis was performed using all deaths present in the Mortality Information System (SIM) in the period from 2007 to 2012 , in males with the age of 20 years old or older, living in the 22 municipalities of Acre, whose occupations were coded CBO: 600-6395 equivalent to ISCO: 6111-6340, and activities related to rural works.

To analyze the CMOR, sample death certificates were separated into two groups; the first one including all cancer deaths (ICD C00 - C97) and the second one from other causes of death. For each of these groups was followed the same age division previously mentioned and used the same reference population. To compute the CMOR, the exposure group was formed by the set of deaths occurred among rural workers, all deaths from other causes in the same population, age and period were used as control.

Based on these data, the CMOR and their respective 95\% confidence intervals according to the distribution of Poisson ${ }^{9}$ were calculated for the set of all neoplasms and for specific types of neoplasms were occurred at least one death among rural workers. 
Microsoft Office Excel programs, Office Access 2007 and SPSS 17.0 for Windows were used for statistical analysis; the first ones to compile cases and build the graphics and the third one to calculate the $p$ value.

The research was approved by the Research Ethics Committee of the Universidade Federal do Acre with the Report Number: 202.422 in 02/14/2013 according to the Resolution No. 466/2012 of the Conselho Nacional de Ética em Pesquisa - CONEP (National Council of Research Ethics).

\section{RESULTS}

According to the electronic database available at the High Complexity Unit in Oncology (UNACON) in Rio Branco, 3.715 people were assisted since the unit started to operate, in the period from June 2007 to July 2012. From these people, $56.9 \%$ were female patients and the predominant age group was from 40 to 79 years old in both sexes, both representing $71 \%$ of the cases studied.

Considering that the State of Acre boundaries countries like Peru and Bolivia, and it boundaries some Brazilian cities in the states of Rondônia and Amazonas, which geographical location are closer to the capital Rio Branco than to the capitals of their respective states, many patients migrate searching for oncology care at UNACON, which represent $3.8 \%$ of all medical assistance during the period.
According to the purpose of this study only the cases of male cancer were analyzed, especially the ones living in Rio Branco, in a total of 958 incident cases in the period. Prostate cancer was the most common one (28.2\%), followed by the cancer of the oral cavity and pharynx (9.6\%), respiratory system $(8.8 \%)$, stomach (7.5\%), skin (7.0\%), and leukemia (5.3\%).

The characterization of the occupational profile of the patients required medical record searches. We located 958 records but only 689 were analyzed. Through this search wenoted the absence of occupation records in $24.1 \%$ of the cases. The papers where the occupation was informed and recorded showed a predominance of occupation related to rural works, according to the International Standard Classification of Occupations (ISCO $)^{7} .8 .6 \%$ of the patients were farmers and $7.4 \%$ were rubber tappers. 184 patients said their occupation was related to rural works and this number was used to calculate the PCIR on this study.

The results of the Proportional Cancer Incidence Ratio (PCIR) that use as reference Rio Branco's population, Cuiabás population, Goiânia’s and Belém’s population are presented in Table 1 . These results were represented by age, in separate age group in 10 years intervals, to 70 years and more, according to the form of the representation of data at the Population Based Cancer Estimated $(2007-2012)^{10}$.

Table 1. Proportional Cancer Incidence Ratio (PCIR), age adjusted in rural workers treated at UNACON (2007-2012). Standard population - Rio Branco, Cuiabá, Goiânia and Belém

\begin{tabular}{|c|c|c|c|c|c|}
\hline ICD - 10 & Anatomical Location & $\begin{array}{l}\text { PCIR Rio Branco* } \\
\text { PCIR }(95 \% \text { CI) }\end{array}$ & $\begin{array}{l}\text { PCIR Cuiabá } \\
\text { PCIR (95\% CI) }\end{array}$ & $\begin{array}{l}\text { PCIR Goiânia } \\
\text { PCIR (95\% CI) }\end{array}$ & $\begin{array}{l}\text { PCIR Belém } \\
\text { PCIR (95\% CI) }\end{array}$ \\
\hline C00 - C14 & Oral cavity and pharynx & $1.14(0.49-2.25)$ & $0.70(0.30-1.37)$ & $0.77(0.33-1.53)$ & $0.77(0.33-1.51)$ \\
\hline $\mathrm{C} 15$ & Esophagus & $0.34(0.01-1.88)$ & $0.13(0.00-0.75)$ & $0.20(0.01-1.12)$ & $0.25(0.01-1.41)$ \\
\hline $\mathrm{C} 16$ & Stomach & $0.68(0.40-1.07)$ & $1.37(0.81-2.17)$ & $1.41(0.84-2.23)$ & $0.50(0.30-0.79)$ \\
\hline $\mathrm{C} 18-\mathrm{C} 21$ & $\begin{array}{l}\text { Colon, Rectum-sigmoid } \\
\text { junction/anus }\end{array}$ & $0.41(0.11-1.05)$ & $0.33(0.09-0.85)$ & $0.28(0.08-0.72)$ & $0.48(0.13-1.23)$ \\
\hline $\mathrm{C} 22$ & Liver and biliary tract & $0.37(0.01-2.04)$ & $0.49(0.01-2.74)$ & $0.32(0.01-1.79)$ & $0.14(0.00-0.76)$ \\
\hline $\mathrm{C} 25$ & Pancreas & $3.40(0.92-8.70)$ & $1.51(0.41-3.86)$ & $1.73(0.47-4.44)$ & $0.96(0.26-2.45)$ \\
\hline C30 - C31 & Nasal cavity/paranasal sinuses & $1.92(0.05-10.69)$ & $2.99(0.08-16.64)$ & $2.43(0.06-13.51)$ & $2.14(0.05-11.90)$ \\
\hline $\mathrm{C} 32$ & Larynx & $7.55(4.23-12.46)$ & $2.31(1.29-3.81)$ & $3.36(1.88-5.55)$ & $2.78(1.56-4.60)$ \\
\hline C33 - C34 & Trachea, lung and bronchus & $0.20(0.05-0.51)$ & $0.23(0.06-0.59)$ & $0.27(0.07-0.69)$ & $0.14(0.04-0.35)$ \\
\hline $\mathrm{C} 43$ & Melanoma & $11.44(6.55-18.54)$ & $10.05(5.75-16.28)$ & $5.16(2.95-8.35)$ & $14.02(8.02-22.71)$ \\
\hline $\mathrm{C} 49$ & Connective tissue & $1.92(0.05-10.69)$ & $0.75(0.02-4.18)$ & $0.84(0.02-4.70)$ & $0.54(0.01-2.98)$ \\
\hline $\mathrm{C} 60$ & Penis & $0.60(0.02-3.33)$ & $0.78(0.02-4.36)$ & $0.53(0.01-2.94)$ & $0.88(0.02-4.93)$ \\
\hline C61 & Prostate & $0.88(0.70-1.09)$ & $1.09(0.87-1.36)$ & $1.11(0.88-1.39)$ & $2.50(2.00-3.13)$ \\
\hline C62 & Testis & $3.40(0.09-18.94)$ & $1.15(0.03-6.42)$ & $1.66(0.04-9.27)$ & $1.85(0.05-10.29)$ \\
\hline C64 - C66 & Kidney & $1.50(0.55-3.27)$ & $1.69(0.62-3.68)$ & $1.03(0.38-2.24)$ & $0.87(0.32-1.91)$ \\
\hline C67 & Bladder & $3.68(0.76-10.75)$ & $0.91(0.19-2.66)$ & $0.69(0.14-2.02)$ & $1.28(0.26-3.74)$ \\
\hline C69 & Eye & $0.58(0.01-3.22)$ & $2.16(0.05-12.01)$ & $1.78(0.05-9.91)$ & $5.04(0.13-28.06)$ \\
\hline C70 - C72 & Brain & $0.92(0.02-5.12)$ & $0.23(0.01-1.30)$ & $0.28(0.01-1.54)$ & $0.34(0.01-1.87)$ \\
\hline C73 - C75 & Endocrine glands & $3.02(0.82-7.73)$ & $3.61(0.98-9.25)$ & $2.78(0.76-7.13)$ & $3.49(0.95-8.93)$ \\
\hline C82-C85 & Lymphoma no- Hodgkin & $10.00(5.17-17.50)$ & $3.77(1.95-6.60)$ & $2.34(1.21-4.09)$ & $3.52(1.82-6.16)$ \\
\hline C91 - C95 & Leukemia & $0.46(0.06-1.65)$ & $0.57(0.07-2.07)$ & $0.33(0.04-1.18)$ & $0.53(0.06-1.93)$ \\
\hline
\end{tabular}

${ }^{\star}$ Hospital Cancer Registry - RCBP of Rio Branco by Nakashima et al. ${ }^{10}$; Source: Unit of High Complexity in Rio Branco Oncology and RCBP/INCA by Brasil ${ }^{11}$ 
Using as a reference to Rio Branco population, we observed a high PCIR and statistically significant for laryngeal tumors (PCIR 7.55, 95\% CI 4.23 to 12.46), melanoma (PCIR 11.44, 95\% CI 6.55 - 18.54) and non - Hodgkin lymphoma (PCIR 10.00, 95\% CI 5.17 - 17.50). The lip cancer, oral cavity and pharynx, pancreas, nasal cavity, paranasal sinuses and ear tissue, testis, kidney, endocrine glands and bladder showed high PCIR, but no statistical significance.

By using the population of Cuiabá as a reference, we noted a high and statistically significant PCIR for laryngeal neoplasms (PCIR 2.31, 95\% CI 1.29 -3.81), melanoma (PCIR 10.05, 95\% CI 5.75 - 16.28) and lymphoma - Hodgkin (PCIR 3.77, 95\% CI 1.95 - 6.60). Other anatomical sites with a high PCIR, but no statistical significance, were stomach, pancreas, nasal cavity, paranasal sinuses and ears, prostate, testis, kidney, eyes and attachments and endocrine glands.

Table 1 shows the analysis of the PCIR results using the population of Goiânia as a reference. We noted a high and statistically significant PCIR for laryngeal neoplasms (PCIR 3.36, 95\% CI 1.88 - 5.55), melanoma (PCIR 5.16, 95\% CI 2.95 - 8.35) and non-Hodgkin lymphoma (PCIR 2.34, IC 95\%1.21 - 4.09). Other anatomical sites with had high PCIR, but no statistical significance, were nasal cavity, paranasal sinuses and ears and endocrine glands.

The results of PCIR, using the population of Belém as a reference, was verified a high PCIR and statistically significant for laryngeal neoplasms (PCIR 2.78, 95\% CI 1.51 - 4.60), melanoma (PCIR 14.02, 95\% CI 8.02 - 22.71), prostate (PCIR 2.50, 95\% CI 2.00 - 3.13) and non - Hodgkin lymphoma (PCIR 3.52, 95\% CI 1.82 - 6.16). Other anatomical sites with a high PCIR, but no statistical significance, were nasal cavity, paranasal sinuses and ears, eyes and attachments and endocrine glands.

Table 2 shows the results of calculation of Cancer Mortality Odds Ratio (CMOR) by the different anatomical sites of cancer for male farm workers. Significant excess was found only for pancreatic neoplasms (CMOR 6.94, 95\% CI 1.73 - 27.89) and malignant neoplasms of the urinary tract (CMOR 13.89, 95\% CI 1.25 - 153.60); a discreet but not significant excess was observed for cancers of the liver and biliary tree, larynx, melanoma and lymphoma for non - Hodgkin.

\section{DISCUSSION}

One of the main sources of exposure to carcinogenic substances is the workplace. Agricultural work is a potentially harmful occupation; it exposes rural workers to various agents that can harm their health ${ }^{13}$. Farmers and rubber tappers skin and airways are easily exposed to these agents as solar radiation, pesticides, solvents, fumes and gases containing hydrocarbons and benzene during the work time. There is considerable evidence of accumulation on the carcinogenic action of these chemicals used in agriculture, especially pesticides ${ }^{14,16}$.

The International Agency for Research on Cancer (IARC) ${ }^{12}$ recognizes sufficient evidence on the carcinogenicity of 18 pesticides and other evidence to 16 . The high exposure to pesticides is one of the hypotheses proposed to explain the increased incidence of certain cancers observed among farmers ${ }^{17,18}$.

Organochlorines, chemical products that we can find in pesticides, belong to Group 2B carcinogens by IARC, DDT, dichlorodiphenyltrichloroethane, and are associated with the development of liver cancer, lung and lymphoma in laboratory animals ${ }^{6}$. In the case of solar radiation and rubber industry agents, classified in Group I, there are sufficient evidence of carcinogenicity in human beings ${ }^{12,16}$.

According to the World Health Organization, developing countries consume $20 \%$ of all pesticides produced in the world ${ }^{15}$. In Brazil, where studies on the impact of exposure to these compounds on cancer morbidity and mortality profile are rare, public health is a problem, because the country is currently the world's largest consumer of pesticides, corresponding, in Latin America, to $86 \%$ of products used ${ }^{15,19}$.

Table 2. Cancer Mortality Odds Ratio (CMOR) for rural workers, male, in the State of Acre, Brazil, 2007-2012

\begin{tabular}{llccc}
\multicolumn{1}{c}{ ICD-10 } & \multicolumn{1}{c}{ Anatomic Location } & CMOR & 95\% CI & \multicolumn{1}{c}{$\boldsymbol{p}$} \\
C00-C97 & All Sites & 1.02 & $0.75-1.39$ & $1.00^{*}$ \\
C00-C14 & Oral cavity and pharynx & 0.98 & $0.12-7.99$ & 1.00 \\
C16 & Stomach & 0.94 & $0.33-2.69$ & $0.38^{\star}$ \\
C22 & Liver and biliary tract & 1.55 & $0.58-4.12$ & $\mathbf{0 . 0 1}$ \\
C25 & Pancreas & $\mathbf{6 . 9 4}$ & $\mathbf{1 . 7 3 - 2 7 . 8 9}$ \\
C30-C34 & Respirator & 0.89 & $0.38-2.10$ & 0.79 \\
C32 & Larynx & 4.63 & $0.77-27.80$ & $0.12^{*}$ \\
C33-C34 & Trachea, lung and bronchus & 0.67 & $0.24-1.90$ & $0.64^{*}$ \\
C43-C 44 & Melanoma & 2.31 & $0.24-22.32$ & $0.41^{*}$ \\
C61 & Prostate & 1.03 & $0.50-2.09$ & 0.93 \\
C64-C68 & Malignant neoplasms of urinary tract & $\mathbf{1 3 . 8 9}$ & $\mathbf{1 . 2 5}-\mathbf{1 5 3}^{*}$ \\
C85 & Lymphoma no- Hodgkin & 1.73 & $0.19-15.58$ \\
\hline
\end{tabular}

*Fisher's exact test; Source: Mortality Information System - SIM (2007-2012) provided by Epidemiological Surveillance, State Secretary Health - Acre -Brazil 
Studies suggest that residents of farming communities have lower mortality from all causes compared to the population in general. However, individuals with agricultural occupations and residents of rural communities have a higher mortality for some specific cancers such as leukemia, non-Hogdkin lymphoma, multiple myeloma, lip cancer, prostate and stomach, among others. The main hypothesis of this increased mortality is the exposure to pesticides ${ }^{18,20}$.

The occupational history of the Amazon region, where the state of Acre is located, allowed us to conduct an exploratory study on the exhibition contribution to rural activities, prevalent in the region, the occurrence of cancer. However, the approach used in this study regarding the establishment of occupational exposure, and the deficiencies in the availability of data on cancer may have underestimated the results.

A significant risk was observed for laryngeal tumors, melanoma and lymphoma not-Hodgkin in the group of rural workers when compared to Rio Branco, Cuiabá, Goiânia and Belém populations. Studies conducted by Rushton et al. ${ }^{21}$, rubber tappers had shown a high number of cancer cases of bladder, larynx and hypopharynx. These authors also strongly associated the occurrence of melanoma skin cancer in farmer workers.

In addition, pancreatic cancer, bladder and non-Hodgkin lymphoma are most frequent types of cancer related to rural workers due to the exposure to pesticides (insecticides, fungicides and herbicides organochlorines, organophosphates and carbamates) used by farmers ${ }^{21-23}$.

In a systematic review, 23 out of 27 studies on lymphoma cancer were associated with non-Hodgkin (LNH) type in farmers ${ }^{24}$. Most of them were men, usually adults, who worked as farmers, pesticide applicators in pesticide factories, landscapers or timber. Studies have shown an increased risk, and many showed the dose-response associations. Agricultural health studies also recount epidemiological evidence of increased risk of LNH by exposure to pesticides and solvents with increasing exposure ${ }^{25,26}$.

Several epidemiological studies have reported an increased risk of prostate cancer among farmers ${ }^{19,27}$. A case-control study conducted in Canada found a significant association between the risk of prostate cancer and exposure to DDT (OR 1.68, 95\% CI $1.04-2.70$ for high exposure), simazine (OR 1.89, 95\% CI 1.08 - 3.33 in high exposure) and lindane (OR 2.02, 95\% CI 1.15 - 3.55 for high exposure) ${ }^{27}$. In this study, conducted with the population of Belém, rural workers showed a significant increase in the risk of prostate cancer. In an ecological study conducted in Brazil, correlations were statistically found even though not significant between the exposure to pesticides and mortality rates from prostate cancer $(\mathrm{r}=0.67)$, and testis $(\mathrm{r}=0.53)$, supporting those findings ${ }^{19}$.
In this study, rural workers showed a frequency of cases of neoplasia of nasal cavities, paranasal sinus and ear, testicular endocrine glands higher than expected when compared to the four populations of reference, although none of the PCIR was statistically significant. The wood dust is considered carcinogenic to the paranasal sinuses ${ }^{12}$. Many rural workers also deal with the timber industry in the region studied, even if it is not the main activity performed. In a study conducted in Belém, with workers in the timber industry, an excess risk for this neoplasm was observed, however also not statistically significant ${ }^{28}$.

The comparison between Rio Branco's and Belém's populations allowed to verify an excess of bladder cancer cases, but not statistically significant. However, international researchers have reported an increased incidence of bladder cancer in imazethapyr pesticide applicators (RR 2.37, 95\% CI 1.20 - 4.68) compared to unexposed applicators, and observed dose-response pattern significant ${ }^{29}$.

It was observed a high PCIR for pancreatic cancer in farmer workers, compared to the population of Rio Branco, though not statistically significant. However, evidence was found by researches. In a survey conducted about the exposure to specific pesticides, pesticide applicators of S-ethyl-dipropylthiocarbamate types (EPTC) (RR 2.50, 95\% CI 1.10 - 5.40) and pendimethalin (RR 3.00; 95\% CI 1.30 - 7.20) there was an increased risk of pancreatic cancer compared to unexposed applicators and it was a significant trend of dose response for exposure to both herbicides ${ }^{30}$.

The presence of high PCIR statistically significant or not, to the same kind of cancers in the four populations of reference, suggests epidemiological evidence about the occurrence of specific neoplasia in rural workers in Rio Branco, Acre.

The analysis of the Cancer Mortality Odds Ratio (CMOR) by different anatomical sites suggests a significant excess of deaths for pancreatic neoplasms (CMOR 6.64, CI 95\% 1.73 - 27.89) and urinary tract (CMOR 13.89, 95\% CI 1.25 - 153.60) among rural workers. A study with farmers in the state of Paraná, in Brazil, described an association between the occupational exposure and mortality from pancreatic cancer (MOR 1.83, 95\% CI $1.36-2.41)^{31}$. A systematic review of studies reinforces the epidemiological evidence of the relationship between pancreatic cancer and exposure to pesticides ${ }^{24}$. Three studies associated the increased risk and the presence of dose-response effect ${ }^{24}$.

The significant risk of deaths for neoplasms of the urinary tract, in a systematic review, six papers showed a relation between the pesticide exposure and kidney cancer, and all results showed positive association $s^{24}$. In a study in a local population in the outskirt of a former factory in Rio de Janeiro, a place contaminated by pesticides in a polluted area, waste hexachlorocyclohexane (HCH), DDT and pentachlorophenol showed an exploratory analysis of the distribution of cancer mortality revealed elevation 
in mortality from pancreatic cancer, liver, larynx, bladder and hematological tumors in men ${ }^{19}$.

It was also observed an increase in the risk of death for laryngeal carcinomas, skin, non-Hodgkin lymphoma and liver, although not significant statistically. Regarding CMOR for laryngeal cancer is highly relevant given that in this study we found a PCIR also increased in comparison with all records. Farmers aged from 50-69 also had a higher mortality from this type of neoplasm in a Brazilian study ${ }^{15}$.

There was no significant increase at the risk for all of the anatomical sites (CMOR 1.02, 95\% CI 0.75 - 1.39). It is possible that this result may be related to the "healthy worker effect". However, the effect detected, apparently contradictory, it is not unusual. Researchers point out that the presence of healthy worker effect is perceived both in external and internal comparisons occupational studies $^{32}$. On the other hand, rural works have been related, in literature, to the development of cancer in specific sites and thus not be expected, that was observed a greater risk of cancer in general among these workers.

An important limitation of this study is related to the unavailability of information on others risk factors known to be associated with the development of cancer, such as smoking and alcohol, among others. Another limitation consists in the exposition as a determiner.

Although necessary, it is not possible to estimate the levels of exposure of each carcinogen agent present in the production of multiple carcinogens used in rural works. The reason is that there is not appropriate technical and feasible to identify and measure each individual exposure ${ }^{5}$. The lack of an occupational history prevented the confirmation of this data could contribute to errors in the occupation classification of the individuals studied.

The alternative to overcome these difficulties was the use of indirect classifications for exposure, since that one was determined by the individual's occupation at the time of hospitalization or death ${ }^{5}$.

According to Ribeiro \& Wünsch Filho, the title of occupation, as an approximation of the exposure situation, is possible in epidemiological studies of occupational nature. Because of it we suggested the use of classifications, which will allow comparisons between different studies in populations from different regions or over a period of time ${ }^{5}$. It was done in this study as it is recommended in the International Standard Classification of Occupations (ISCO) ${ }^{7}$.

Despite these various limitations, the study identified tumor sites with statistically significant excess risk in the occurrence of cancer for laryngeal tumors, melanoma, non-Hodgkin's lymphoma and prostate and mortality pancreas and urinary tract infections, which are consistent with the literature.

Monitoring the mortality and the incidence of cancer in this occupational group is relevant because the agricultural activity is a significant part of the economy in the state of Acre.

\section{CONCLUSION}

There was a significant statistic increase in the proportional distribution of laryngeal cancer, melanoma, non-Hodgkin's lymphoma and prostate in male rural workers treated a unit of Oncology Service in Rio Branco, Acre, Brazil. There was also a high risk of death from pancreatic cancer and urinary tract and increased (though not statistically significant) risk of death from laryngeal carcinomas, skin, non-Hodgkin's lymphoma and liver among such workers.

The results suggest that the incidence and mortality from specific cancers in rural male workers in Acre may be associated with occupational exposure. The causality of these associations can be explored in the future analytical studies in the Amazon.

\section{REFERENCES}

1. World Health Organization. Câncer [Internet]. Geneva; 2012 [cited 2013 Fev. 14]. Available from: http://www.who.int/cancer/en/index.html

2. Souza CAA. História do Acre: novos temas, nova abordagem. 2nd ed. Rio Branco: Ed. Carlos A; 2005.

3. Costa, CAF. Racionalidade e exploração madeireira na Amazônia brasileira [thesis]. Salamanca: Departamento de Sociologia, Universidade de Salamanca; 2004.

4. Instituto Brasileiro de Geografia e Estatística. Mapa do Estado do Acre [Internet]. Rio de Janeiro: IBGE; 2015 [cited 2015 Nov. 15]. Available from: http://mapas.ibge.gov.br/politico-administrativo/estaduais

5. Ribeiro FS, Wünsch Fo V. Avaliação retrospectiva da exposição ocupacional a cancerígenos: abordagem epidemiológica e aplicação em vigilância em saúde. Cad Saúde Pública. 2004;20(4):881-90. http://dx.doi.org/10.1590/ S0102-311X2004000400002. PMid:15300280.
6. Brasil. Ministério do Trabalho e Emprego. Portal do Trabalho e Emprego. CBO - Classificação Brasileira das Ocupações [Internet]. Brasília; 2002 [cited 2014 Apr. 20]. Available from: http://www.mtecbo.gov.br/cbosite/ pages/home.jsf

7. International Labor Organization. International Standard Classification of Occupations (ISCO) [Internet]. 2003 [cited 2014 Apr. 20]. Available from: http://www.ilo.org/stat/langen/index.htm

8. Hennekens CH, Buring J. Epidemiology in medicine. Boston: Little, Brown and Company; 1987. p. 55-97.

9. Lilienfeld AM, Lilienfeld DE. Foundations of epidemiology. New York: Oxford University Press; 1980. p. 302-3.

10. Nakashima JP, Koifman RJ, Koifman S. Incidência de câncer na Amazônia ocidental: estimativa de base populacional em Rio Branco, Acre, Brasil, 2007-2009. Cad de Saúde Pública. 2012;28(11):2125-32. 
11. Brasil. Ministério da Saúde. Instituto Nacional do Câncer. Câncer no Brasil: dados dos Registros de Base Populacional. Rio de Janeiro: INCA; 2010. Vol. 4 [cited 2012 July 20]. Available from: http://www.inca.gov.br/ cancernobrasil/2010/

12. International Agency for Research on Cancer. Lists of IARC evaluations. Complete list of all monographs and supplements published to date [Internet]. Lyon: IARC; 2010 [cited 2012 July 20]. Available from: http:// www.iarc.fr/

13. Meyer A, Alexandre PCB, Chrisman JR, Markowitz SB, Koifman RJ, Koifman S. Esophageal cancer among Brazilian agricultural workers: case-control study based on death certificates. Int J Hyg Environ Health. 2011;214(2):1515. http://dx.doi.org/10.1016/j.ijheh.2010.11.002. PMid:21159552.

14. Brasil. Ministério da Saúde. Instituto Nacional de Câncer. Vigilância do câncer ocupacional e ambiental. Coordenação de prevenção e vigilância. Rio de Janeiro: INCA; 2005.

15. Meyer A, Chrisman J, Moreira JC, Koifman S. Cancer mortality among agricultural workers from serrana Region, state of Rio de Janeiro, Brazil. Environ Res. 2003;93(3):264-71. http://dx.doi.org/10.1016/S00139351(03)00065-3. PMid:14615236.

16. Neves H, Moncau JEC, Kaufmann PR, Wünsch Fo V. Mortalidade por câncer em trabalhadores da indústria da borracha de São Paulo. Rev Saude Publica. 2006;40(2):271-9. http://dx.doi.org/10.1590/S0034-89102006000200013. PMid:16583038.

17. Blair A, Zahm SH, Pearce NE, Heineman EF, Fraumeni Jr JF. Clues to cancer etiology from studies of farmers. Scand J Work Environ Health. 1992;18(4):209-15. http://dx.doi.org/10.5271/sjweh.1578. PMid:1411362.

18. Blair A, Zahm S. Agricultural exposures and cancer. Environ Health Perspect. 1995;103(Suppl 8):205-8. http://dx.doi.org/10.1289/ehp.95103s8205. PMid:8741784.

19. Koifman S, Koifman RJ, Meyer A. Human reproductive system disturbances and pesticide exposure in Brazil. Cad Saúde Pública. 2002;18(2):435-45. http://dx.doi.org/10.1590/S0102-311X2002000200008. PMid:11923885.

20. Acquavella J, Olsen G, Cole P, Ireland B, Kaneene J, Schuman S, et al. Cancer among farmers: a meta-analysis. Ann Epidemiol. 1998;8(1):64-74. http:// dx.doi.org/10.1016/S1047-2797(97)00120-8. PMid:9465996.

21. Rushton L, Bagga S, Bevan R, Brown TP, Cherrie JW, Holmes P, et al. Occupation and cancer in Britain. Br J Cancer. 2010;102(9):1428-37. http:// dx.doi.org/10.1038/sj.bjc.6605637. PMid:20424618.
22. Brasil. Ministério da Saúde. Instituto Nacional de Câncer José Alencar Gomes da Silva. Diretrizes para a vigilância do câncer relacionado ao trabalho. Rio de Janeiro: Ministério da Saúde; 2012.

23. Rushton L, Hutchings SJ, Fortunato L, Young C, Evans GS, Brown T, et al. Occupational cancer burden in Great Britain. Br J Cancer. 2012;107(Suppl 1):S3-7. http://dx.doi.org/10.1038/bjc.2012.112. PMid:22710676.

24. Bassil KL, Vakil C, Sanborn M, Cole DC, Kaur JS, Kerr KJ. Cancer health effects of pesticides: systematic review. Can Fam Physician. 2007;53(10):170411. PMid:17934034.

25. Clapp RW, Jacobs MM, Loechler EL. Environmental and occupational causes of cancer new evidence, 2005-2007. Rev Environ Health. 2008;23(1):1-37. http://dx.doi.org/10.1515/REVEH.2008.23.1.1. PMid:18557596.

26. Purdue MP, Hoppin JA, Blair A, Dosemeci M, Alavanja MC. Occupational exposure to organochlorine insecticides and cancer incidence in the Agricultural Health Study. Int J Cancer. 2007;120(3):642-9. http://dx.doi. org/10.1002/ijc.22258. PMid:17096337.

27. Band PR, Abanto Z, Bert J, Lang B, Fang R, Gallagher RP, et al. Prostate cancer risk and exposure to pesticides in British Columbia farmers. Prostate. 2011;71(2):168-83. http://dx.doi.org/10.1002/pros.21232. PMid:20799287.

28. Bahia SHA, Mattos IE, Koifman S. Cancer and wood-related occupational exposure in the amazon region of Brazil. Environ Res. 2005;99(1):132-40. http://dx.doi.org/10.1016/j.envres.2004.12.005. PMid:16053937.

29. Koutros S, Lynch CF, Ma X, Lee WJ, Hoppin JAH, Christensen CH, et al. Heterocyclic aromatic amine pesticide use and human cancer risk: results from the U.S. Agricultural Health Study. Int J Cancer. 2009;124(5):1206-12. http://dx.doi.org/10.1002/ijc.24020. PMid:19058219.

30. Andreotti GB, Freeman LEB, Hou L, Coble J, Rusiecki JA, Hoppin JA et al. Agricultural pesticide use and pancreatic cancer risk in the Agricultural Health Study cohort. Int J Cancer. 2009;124(10):2495-500. http://dx.doi. org/10.1002/ijc.24185. PMid:19142867.

31. Chrisman JR, Sarcinelli PN, Moreira JC, Koifman RJ, Koifman S, Meyer A. Mortalidade por câncer em agricultores do Estado do Paraná. Cad Saude Colet. 2008;16:597-612.

32. Checkoway H, Pearce N, Hickey JL, Dement JM. Latency analysis in occupational epidemiology. Arch Environ Health. 1990;45(2):95-100. http://dx.doi.org/10.1080/00039896.1990.9935932. PMid:2334237.

Received on: June 18, 2015 Accepted on: Feb. 28, 2016 